\title{
Strategi Pembelajaran Pendidikan Jasmani Berbantu Media Book Creator Digital Dalam Meningkatkan Kemampuan Motorik Kasar Siswa Pada Tingkat Sekolah Dasar
}

Isatul Hasanah ${ }^{1}$, Siti Rodi'ah ${ }^{2}$

1,2 IAIN Tulungagung

Corresponding Author: $\otimes$ sitirodiah163@gmail.com

\section{ABSTRACT}

Penelitian ini dilatarbelakangi oleh masalah yang terjadi dalam proses pendidikan jasmani, olahraga dan kesehatan melalui kajian literature review. Data diambil dari berbagai buku dan artikel ilmiah yang relevan dengan masalah yang akan diteliti. Tujuan dari penelitian ini adalah (1) mendeskripsikan strategi guru dalam menggunakan bahan ajar berupa book creator pada pembelajaran jasmani, olahraga dan kesehatan; (2) Mendeskripsikan dampak penggunaan media book creator digital terhadap peningkatan kemampuan motorik kasar siswa. Hasil penelitian diperoleh bahwa strategi guru dalam menggunakan bahan ajar book creator digital

ARTICLE INFO

Article history: Received

16 July 2021

Revised

20 July 2021

Accepted

25 July 2021 yaitu (1) dengan cara mendesain isi bahan ajar berupa digital dan tidak mengurangi isi atau materi dari bahan ajar cetak. Penerapan book creator digital ini menyesuaikan berbagai gaya belajar siswa yang berbeda. Disebabkan adanya suatu fitur yang ditampilkan melalui gambar dan video. (2) Dampak dari penggunaan book creator digital adalah membantu peserta didik dalam memaksimalkan proses belajar teknik gerak yang benar. Melalui tampilan gerakan-gerkan sederhana berbentuk gambar dan video yang dapat ditiru oleh siswa. Tampilan gambar dan video yang menarik dapat meningkatkan motivasi belajar siswa untuk mempraktekkan gerakan tubuh secara lansgung dan benar. Media ini sangat cocok digunakan dalam pembelajaran di luar maupun di dalam kelas. Adapun strategi guru dalam menggunakan book creator digital ini dalam pembelajaran daring adalah memaksimalkan fitur-fitur yang terdapat pada book creator tersebut melalui kejelasan materi berupa tulisan, kesesuaian gambar dengan materi dan tingkat perkembangan kognitif peserta didik serta kejelasan teknik gerakan tubuh yang ditampilkan dalam bentuk video. Sehingga peserta didik dapat mempraktekkan teknik gerakan secara runtut dan benar melalui media book creator digital.

\section{Keywords}

Strategi Pembelajaran, Media Book Creator Digital, Kemampuan Motorik Kasar

How to cite 


\section{PENDAHULUAN}

Pendidikan jasmani dan olahraga diajarkan pada seluruh jenjang sekolah. Karena memiliki pengaruh penting terhadap keterampilan peserta didik untuk menjaga diri secara mandiri. Penjaskes bertujuan untuk mengembangkan aspek kebugaran jasmani, keterampilan gerak, keterampilan berpikir kritis, keterampilan sosial, penalaran stabilitas emosional, tindakan moral, aspek pola hidup sehat dan pengenalan lingkungan bersih melalui aktivitas jasmani dan olahraga yang direncanakan secara sistematis dalam rangka mencapai tujuan pendidikan nasional (Rismayanthi, 2011). Hal ini didukung oleh aktivitas belajar peserta didik yang berorientasi pada gerakan tubuh. Di mana proses pendidikan jasmani dan olahraga memanfaatkan aktivitas fisik yang melibatkan otot-otot. Berdasarkan paparan di atas, pendidikan jasmani sangat penting untuk diajarkan pada semua jenjang sekolah. Sehingga, guru perlu menggunakan strategi pembelajaran yang tepat untuk meningkatkan keterampilan gerakan tubuh atau motorik peserta didik. Pendidikan jasmani dan olahraga merupakan sarana untuk meningkatkan keterampilan motorik (Rismayanthi, 2011). Perkembangan keterampilan motorik merupakan faktor yang sangat penting bagi perkembangan kepribadian anak secara keseluruhan (Jasmeet Kaur, 2017). Terutama perkembangan kepribadian anak yang mengarah pada tujuan pendidikan jasmani dan olahraga yang telah diuraikan diatas. Sehingga, keterampilan motorik peserta didik perlu didorong agar tujuan pendidikan jasmani dan olahraga tercapai secara maksimal.

Salah satu keterampilan motorik yang perlu didorong oleh peserta didik adalah keterampilan motorik kasar. Karena kemampuan motorik kasar sangat berhubungan dengan kerja otot-otot besar yang ada di dalam tubuh manusia (Bonita Mahmud, 2018). Contohnya adalah berlari dan melompat yang pada umumnya dikenal dalam pendidikan jasmani sebagai keterampilan motorik dasar (A Cherly, 2004). Melalui keterampilan motorik yang baik, maka proses bergerak peserta didik ke sekitar pada lingkungannya menjadi lebih otomatis (Nur, 2019). Hal ini berdampak pada kemudahan peserta didik dalam menjaga diri secara mandiri. Selain itu, peserta didik lebih mudah dalam beraktivitas fisik untuk menjaga kebugaran tubuhnya.Pengembangan ketrampilan motorik kasar sangat baik dikembangkan pada peserta didik yang masih berada di jenjang Sekolah Dasar (SD). Pasalnya, anak usia Sekolah Dasar (SD) merupakan anak dengan kategori banyak mengalami perubahan yang sangat drastis, baik mental maupun fisik (Rismayanthi, 2011). Keterampilan motorik kasar pada peserta didik sangat berhubungan dengan kerja otot-otot besar. Sehingga masa perubahan yang sangat drastis pada peserta didik di jenjang Sekolah Dasar (SD) memberikan dampak pada pengembangan keterampilan motorik kasar yang baik.

Selama pandemi covid-19 ini, kegiatan pembelajaran diarahkan secara virtual atau online dengan memanfaatkan teknologi dan informasi. Artinya pembelajaran tidak berlangsung secara tatap muka yaitu antara guru dan peserta didik bertemu secara langsung pada suatu ruangan seperti ruang kelas. Tetapi, pembelajaran 
diarahkan pada sistem online atau dikenal dengan Pembelajaran Jarak Jauh (PJJ). Tentu, proses pendidikan jasmani dan olahraga akan mengalami perubahan. Yaitu dari guru memberikan contoh keterampilan gerakan dasar yang dilanjutkan praktek peserta didik secara langsung, saat ini diarahkan pada pembelajaran berbasis digital (Kihara, Seiichiro., 2020). Hal ini memberikan kesulitan bagi guru maupun peserta didik dalam mengikuti pembelajaran daring. Berbagai tantangan pada guru dalam mengajar pendidikan jasmani dan olahraga secara daring tidak dapat dielakkan lagi. Karena pembelajaran daring ini merupakan proses transformasi pendidikan konvensional ke dalam bentuk digital sehingga memiliki tantangan dan peluang tersendiri (Maiti \& Bidinger, 2020). Ditinjau dari karakteristik materi pendidikan jasmani dan olahraga mayoritas berhubungan dengan keterampilan motorik. Tentu diperlukan kompetensi guru dalam memanfaatkan teknologi dan informasi pada pembelajaran daring ini. Agar pembelajaran daring dapat mendorong kemampuan motorik peserta didik. Tetapi, berdasarkan kajian literatur dari Seiichiro dan kawankawan bahwa guru terhambat dalam mengembangkan pengalaman belajar karena keterbatasan pengetahuan konten mereka tentang pendidikan jasmani Hal ini diperlukan solusi praktis, agar pembelajaran jasmani dan olahraga ini berlangsung secara efektif.

Berdasarkan temuan di lapangan bahwa sarana dan prasarana untuk menunjang keefektifan pembelajaran jasmani dan olahraga di jenjang Sekolah Dasar (SD) secara daring belum memadai. Secara umum materi pendidikan jasmani dan olahraga identik dengan keterampilan gerak tubuh. Guru hanya mengandalkan buku LKS, buku siswa, serta pengambilan video pembelajaran dari youtube dengan menyesuaikan konten yang akan diajarkan kepada peserta didik. Disisi lain, bahan ajar yang digunakan oleh siswa tidak sepenuhnya terealisasi dalam bentuk praktek. Untuk menunjang kemampuan motorik kasarnya, peserta didik mengandalkan informasi yang diberikan oleh guru dalam bentuk video pembelajaran. Tetapi, banyak peserta didik yang belum bisa mempraktekkan gerakan tersebut secara benar. Hal ini didukung oleh temuan dari Ricky dan Erry pada hasil penelitiannya bahwa pada jenjang Sekolah Dasar (SD) pada umumnya siswa belum mampu menguasai teknik dasar dalam suatu kegiatan pembelajaran jasmani dan olahraga (Ricky Wirasasmita., 2020). Padahal belajar gerak dengan teknik yang baik dan benar akan memberikan kontribusi yang sangat besar terhadap pengalaman belajar gerak lanjutan yang memungkinkan lebih kompleks (Dicky Tri Junior, 2019). Sehingga, strategi pembelajaran daring yang dilakukan oleh guru belum efektif.

Paparan di atas menunjukkan bahwa peranan teknologi sangat esesnsial dalam mendukung pembelajaran daring untuk mendorong keterampilan motorik kasar peserta didik. Menurut Jung dan Zan dalam kajian literatur memaparkan bahwa penggunaan teknologi digital dalam pembelajaran pendidikan jasmani dapat meningkatkan motivasi siswa untuk mengembangkan kemampuan motoriknya yaitu dengan cara menyusun rencana pembelajaran yang dibuat dengan baik dan terstruktur dengan bantuan teknologi (Lee, Eun, Jun., \& Gao, : 2020). Selain didukung dengan 
perencanaan pembelajaran jasmani dan olahraga yang baik serta terstruktur, penggunaan bahan ajar menarik berbasis digital pun dapat mendukung pembelajaran daring lebih efektif. Tetapi, pembelajaran yang efektif memerlukan pemahaman menyeluruh tentang proses pembelajaran, perkembangan karakteristik siswa, perbedaan individu, faktor-faktor yang mempengaruhi motivasi peserta didik (Sri Weni Utami, 2019). Penggunaan bahan ajar berbasis digital merupakan salah satu pemanfaatan teknologi dalam memberikan pengalaman belajar terhadap peserta didik. Terutama pada aspek pengetahuan dasar tentang gerakan tubuh yang benar. Sehingga tujuan pembelajaran jasmani dan olahraga dapat tercapai. Di mana tujuan penelitian ini adalah peningkatan keterampilan motorik kasar peserta didik. Berdasarkan penjelasan dari Sri Weni yang telah dipaparkan di atas, maka bahan ajar berbasis digital harus diperhatikan. Baik dari segi alur pembelajaran, karakteristik siswa, perbedaan individu, maupun faktor-faktor yang mempengaruhi motivasi belajar peserta didik.

Berdasarkan teori perkembangan kognitif bahwa peserta didik pada jenjang Sekolah Dasar (SD) berada pada tahap konkret operasional yang artinya untuk memahami suatu konsep anak harus diberikan kegiatan yang berhubungan dengan kejadian nyata yang dapat diterima akal mereka (Muhibbin Syah, 2011). Ditinjau dari perbedaan individu, tentu gaya belajar peserta didik berbeda-beda, yaitu visual, audio visual, dan kinestetik. Sedangkan salah satu faktor yang mempengaruhi motivasi belajar pendidikan jasmani dan olahraga adalah penggunaan teknologi digital yang telah dipaparkan sebelumnya. Temuan Jung dan Zan memaparkan bahwa menambahkan konten permainan pada konten teknologi yang digunakan pada pembelajaran jasmani memiliki pengaruh positif terhadap aktivitas fisik anak (Lee, Eun, Jun., \& Gao,: 2020). Sehingga, bahan ajar berbasis digital yang digunakan oleh guru harus memenuhi komponen-komponen sebagaimana yang telah diuraikan. (Testiani Makmur., 2019)

Salah satu bahan ajar berbasis digital yang sesuai dengan komponen-komponen yang telah diuraikan dan dapat dijadikan sumber belajar peserta didik adalah book creator digital. Yaitu sebuah aplikasiang terdiri dari teks, gambar, maupun suara dan dipublikasikan dalam bentuk digital yang dapat dibaca di komputer maupun perangkat elektronik lainnya seperti android, smartphone, atau tablet (Nasrul Makdis, 2020). Book creator dipandang sesuai dengan kemampuan koginitif peserta didik untuk meningkatkan kemampuannya, baik dalam kemampuan berbicara, menulis, menyimak dan membaca (Verdiana Puspitasari, 2020). Melalui fitur-fitur yang tersedia pada book creator digital, maka dapat ditambahkan gambar, video, animasi yang dapat memfasilitasi gaya belajar peserta didik yang beragam. Selain itu, guru dapat menambahkan kuis berupa permainan sederhana yang disesuaikan kemampuan kognitif peserta didik. Sehingga, bahan ajar berupa book creator digital dapat meningkatkan motivasi belajar peserta didik serta memberikan pengalaman belajar yang bermakna. Karena tampilannya dan susunan materi dikemas sesuai dengan perkembangan kognitif dan gaya belajar peserta didik. 
Ada beberapa kelebihan dari book creator digital yaitu pembuatannya sangatlah sederhana (Nurhannisah, 2017). Hal ini memudahkan guru untuk membuatnya sendiri untuk dijadikan bahan ajar peserta didik di masa pembelajaran luring maupun tatap muka. Selain itu, bahan ajar book creator digital mudah didistribusikan oleh guru kepada peserta didik (Verdiana Puspitasari, 2020). Melalui smartphone, guru dapat mengirimkan langsung bahan ajar digital tersebut kepada peserta didik. Bahan ajar book creator digital sangatlah praktis dan mudah dibawa (Ruddamayanti, 2019). Hal ini memudahkan peserta didik untuk belajar pendidikan jasmani dan olahraga dimana saja. Mereka dapat belajar kelompok dengan teman sebaya untuk meningkatkan motivasi belajar, maupun dapat belajar sendiri di rumah dengan mempelajari materi yang telah tersedia di dalamnya. Karena book creator digital dapat dibuka melalui smartphone yang memiliki ukuran sedang dan ringan dibawa kemana-mana. Tentu, pembelajaran di masa pandemi covid-19 ini, penggunaan bahan ajar book creator digital memudahkan guru maupun peserta didik untuk melakukan kegiatan belajar mengajar secara daring.

Berbagai kelebihan dari book creator digital perlu didukung dengan strategi guru dalam memberikan pembelajaran pendidikan jasmani dan olahraga kepada peserta didik. Karena aktivitas pembelajaran memerlukan strategi agar rangkaian kegiatan yang akan dilakukan dapat mencapai tujuan yang diharapkan (Edward Purba, 2015). Strategi pembelajaran yang baik akan berpengaruh terhadap peningkatan keterampilan motorik kasar pada peserta didik. Tentu, keberadaan guru yang bermutu merupakan syarat mutlak hadirnya sistem dan praktik pendidikan yang berkualitas (Harry Pramono, 2012). Guru merupakan ujung tombak dan pelaksana terhadap pendidikan anak-anak di sekolah dan sebagai pengembangan kurikulum (Suci\&Damrah, 2020). Sehingga keberadaan book creator digital sebagai bahan ajar dapat mendorong keterampilan motorik kasar peserta didik yang didukung dengan penggunaan strategi guru yang baik.

Strategi pembelajaran bukan hanya terbatas pada prosedur kegiatan, melainkan termasuk seluruh komponen materi atau paket pembelajaran dan pola pembelajaran itu sendiri (Edward Purba, 2015)Pembelajaran pada masa pandemi covid-19, guru dituntut untuk lebih banyak memberikan praktek kepada peserta didik secara langsung dan melakukan penilaian kompetensi yang berpatokan pada nilai (Suci, 2020). Tentu penggunaan bahan ajar book creator digital ini, guru perlu menyusun materi sesuai kemampuan kognitif, keberagaman gaya belajar dan karakteristik peserta didik yang berorientasi pada teknik gerakan tubuh yang benar. Hal ini akan memudahkan peserta didik untuk mempraktekkan gerakan tersebut dengan benar. Sehingga, melalui penggunaan book creator digital dengan strategi yang tepat, guru dapat memberikan pengetahuan baru dan menciptakan pembelajaran daring yang aktif dan menyenangkan. Melalui strategi pembelajaran penjaskes dengan memanfaatkan book creator digital, peserta didik menjadi lebih termotivasi belajar teknik gerakan yang tepat. Dan hasil akhir dari kegiatan belajar mengajar ini, keterampilan motorik kasar peserta didik menjadi meningkat. 
Berdasarkan uraian di atas, penulis tertarik untuk melaksanakan Penelitian Literature Review dengan judul "Strategi Pembelajaran Pendidikan Jasmani Berbantu Book Creator Digital Dalam Meningkatkan Kemampuan Motorik Kasar Siswa Pada Tingkat Sekolah Dasar". Penelitian ini bertujuan untuk mendeskripsikan strategi guru dalam menggunakan bahan ajar melalui media book creator pada pembelajaran jasmani dan olahraga. Serta dampak penggunaan media book creator digital terhadap peningkatan kemampuan motorik kasar siswa.

\section{METODE PENELITIAN}

Metode penelitian yang digunakan adalah metode literature review yaitu penelitian yang mengambil dan mengolah data dari beberapa jurnal, buku yang telah dipublikasikan dan relevan dengan permasalahan yang akan diteliti. Data yang telah diperoleh, kemudian dianalisis dengan menggunakan analisa deskriptif yaitu dimulai dari pengumpulan data, menganalisis kebutuhan, merumuskan pokok-pokok bahasan yang akan dikaji dan diambil kesimpulan. Subyek dalam penelitian ini adalah siswa/siswi pada jenjang Sekolah Dasar (SD). Fokus penelitian ini adalah kendala proses pembelajaran pendidikan jasmani, olahraga dan kesehatan yang sedang terjadi saat ini. Teknik pengumpulan data dengan metode literature review terdiri dari dua macam yaitu teknik yang sifatnya interaktif dan non interaktif. Tetapi pada penelitian ini, penulis hanya fokus pada teknik yang sifatnya non interaktif yaitu berupa dokumen-dokumen dari berbagai sumber referensi.

\section{HASIL PENELITIAN DAN PEMBAHASAN}

Strategi pembelajaran merupakan salah satu cara yang digunakan oleh guru dalam menyampaikan materi pembelajaran (Syarif Sumantri, 2017). Dalam proses pembelajaran luring maupun daring, strategi sangatlah dibutuhkan untuk memaksimalkan proses pembelajaran. Terlebih, saat ini pembelajaran dilakukan dengan sistem daring. Tentu, guru harus mampu memilih strategi yang tepat dalam memaksimalkan proses pembelajaran. Saat ini dunia telah memasuki era globalisasi yang ditandai dengan adanya perkembangan teknologi informasi dan telekomunikasi. Teknologi yang berkembang secara pesat ini, tentu menuntut semua masyarakat untuk merespon adanya kemajuan tersebut. Salah satu bidang yang mempunyai peluang dalam memanfaatkan teknologi pada proses pembelajaran adalah bidang pendidikan (Lies Sudibyo, 2011).Hal ini memberikan motivasi bagi guru untuk menyusun strategi pembelajaran ke arah pemanfaatan teknologi informasi dan telekomunikasi. Salah satu strategi pembelajaran yang tepat pada masa pandemi covid-19 ini adalah melibatkan sebuah media pembelajaran yang berbasis teknologi. Karena kondisi pembelajaran pada masa pandemi ini, siswa tidak dapat bertemu secara tatap muka dengan guru maupun teman sekelasnya. Sistem pembelajaran harus dilakukan secara daring dengan memanfaatkan media virtual. 
Secara umum, media memiliki arti sebagai sarana komunikasi (Isran Rasyid Karo-Karo S, 2018). Tetapi dalam konteks bidang pendidikan, media dapat diartikan sebagai alat bantu yang dapat dijadikan sebagai penyalur pesan seorang guru untuk mencapai tujuan pembelajaran. Dalam proses pembelajaran, media mempunyai peranan penting untuk memudahkan siswa dalam memahami materi yang disampaikan oleh guru. Pembelajaran yang menarik akan berdampak pada perkembangan pengetahuan siswa. Adanya pemanfaatan media dalam proses pembelajaran dapat mendorong motivasi belajar siswa serta memberikan kemudahan kepada siswa untuk memahami materi pelajaran (Babitha Elsa Oommen, 2020). Saat ini, banyak sekali media yang dapat digunakan dalam proses pembelajaran. Hal ini menimbulkan permasalahan baru bagi seorang guru dalam menentukan media pembelajaran yang sesuai dengan kondisi pandemi ini. Tentu, hal ini tidak mudah bagi guru dalam memadu padankan materi dengan sebuah teknologi pada proses pembelajaran. Karena faktor tingkat kompetensi bagi guru dalam mendesain pembelajaran dengan berbantu media digital. Sehingga guru perlu meningkatkan kompetensinya agar mampu beradaptasi dengan situasi ini. Dimana guru dituntut untuk memanfaatkan berbagai macam teknologi pada kegiatan pembelajaran daring ini .

Tujuan pemanfaatan media dalam proses pembelajaran bukan hanya untuk memberikan materi pelajaran secara interaktif dan dapat mengefesiensikan waktu pembelajaran. Melainkan juga dapa tmenstimulus otak siswa untuk belajar, dan cenderung mengurangi rasa kebosanan yang dialami oleh siswa (Hamalik, 2003). Mc Luhan mengatakan bahwa media adalah suatu eksistensi manusia yang memungkinkannya mempengaruhi orang lain yang tidak mengadakan kontak langsung dengan dia. Yang dimaksud McLuhan dalam pengertiannya adalah, media komunikasi seperti telepon dan surat yang merupakan sebuah jembatan dan memungkinkan seseorang berkomunikasi dengan orang lain. Edgar Dale menyatukan teori belajar yang dikemukakan oleh John Dewey dengan pikiran-pikiran psikologi yang disajikan pada gambarpiramida di bawah ini.

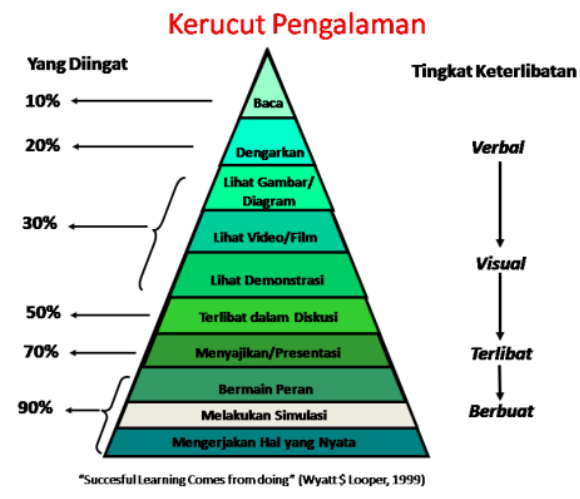

Kerucut pengalaman Edgar Dale mengungkapkan bahwa semakin tinggi puncak kerucut maka pengalaman belajar siswa semakin abstrak, yaitu aktivitas belajar dengan cara membaca (Muhibbin Syah, 2011). Membaca memiliki daya ingat 10\%, 
kebalikannya bermain peran dan turun kelapangan memiliki daya ingat $90 \%$. Karena aktivitas belajar pada bermain peran dan turun ke lapangan, peserta didik mengalami pembelajaran tersebut secara nyata. Media pembelajaran memiliki beberapa jenis yaitu, audio, visual, dan audio-visual. Dari ketiga jenis media pembelajaran tersebut, audio-visual cenderung lebih efektif untuk meningkatkan motivasi siswa karena tidak membuat siswa merasa bosan (Wahyuningtyas \& Sulasmono, 2020). Namun proses belajar mengajar tidak harus dimulai dari pengalaman langsung, Akan tetapi dapat dimulai melalui jenis pengalaman yang sesuai dengan kebutuhan dan kemampuan peserta didik dalam menghadapi situasi belajar. Untuk meningkatkan efektivitas penggunaan media pembelajaran yaitu dengan cara meningkatkan keterampilan yang dimiliki oleh guru dalam menguasai media pembelajaran. Guru harus mampu mengembangkan strategi pembelajaran yang tidak hanya sekedar menyampaikan informasi, melainkan mendorong para siswa untuk meningkatkan motivasi belajar. Penggunaan media yang kreatif dan inovatif dapat mengurangi rasa kebosanan yang dialami oleh siswa dan tidak cenderung monoton. Sehingga peserta didik tidak merasa terhambat dalam memperoleh pengetahuan. Karena peserta didik memiliki motivasi yang tinggi untuk belajar. Kegiatan pembelajaran yang dapat mencapai tujuan pembelajaran harus menggunakan strategi pembelajaran yang baik serta penggunaan media yang tepat.

Pada umumnya, bahan ajar dikenal dalam bentuk cetak (Marsudi, 2013). Dimana seluruh perencanaan pembelajaran ada di dalam bahan ajar. Tetapi, saat ini bahan ajar tidak dapat digunakan secara maksimal. Disebabkan kondisi sekolah dalam menyalurkan bahan ajar secara langsung kurang memadai. Terlebih tidak memungkinkan siswa bisa datang ke sekolah secara langsung. Oleh sebab itu, guru perlu menggunakan strategi pembelajaran berbantu media digital yang di dalamnya berisi tentang materi serta penilaian yang tidak mengurangi isi dari bahan ajar cetak. Penerapan dari media book creator digital ini dalam pembelajaran pendidikan jasmani, olahraga dan kesehatan yaitu seorang guru membuat sebuah materi yang sederhana dan mudah dipahami oleh peserta didik serta memberikan contoh-contoh materi dengan kehidupan sehari-hari. Tujuannya adalah untuk memudahkan siswa dalam memahami materi yang disampaikan oleh guru (Nasrul Makdis, 2020). Strategi guru yang digunakan yaitu dengan cara mengemas isi dari bahan ajar ke dalam bentuk digital. Namun di dalamnya dapat ditambahkan video pembelajaran yang tujuannya untuk mendukung atau memaksimalkan kegiatan pembelajaran. Sehingga, aktivitas belajar dengan book creatur digital memberikan pengalaman yang menarik terhadap peserta didik.

Proses pembelajaran dengan menggunakan strategi pembelajaran yang tepat, tentu membuat pembelajaran menjadi bermakna. Tumbuhnya minat serta ketertarikan siswa juga diperngaruhi dengan adanya treatment yang menyenangkan (Pebria Dheni Purnasari, 2020). Media book creator digital ini merupakan hal yang baru bagi siswa. Sehingga dapat meningkatkan rasa keingintahuan peserta didik. Penggunaan media book creator digital ini tentu dapat digunakan oleh siswa sesuai dengan kebutuhannya 
saat ini (Isran Rasyid Karo-Karo S, 2018). Sehingga media tersebut sangat cocok digunakan dalam proses pembelajaran guna menciptakan pembelajaran yang tidak membosankan. Sesuai dengan pendapat Hamalik bahwa adanya penggunaan media dalam proses pembelajaran tidak hanya dapat menciptakan suasana yang baru, tetapi juga berdampak pada perolehan prestasi belajar peserta didik.

Media book creator digital ini juga terdapat sebuah fitur berisi tentang kejelasan gambar terkait materi yang akan disampaikan. Seyogyanya guru menapilkan gambar yang mendukung kejelasan isi materi tersebut dan tidak menjadikan peserta didik untuk mempraktekkan gerakan. Selain tampilan gambar, book creator digital juga memiliki fitur berupa video. Dimana video pembelajaran yang harus ditampilkan oleh guru mengarah pada hal yang sederhana dan menarik. Sehingga peserta didik mampu memadupadankan isi materi dengan teknik gerakan yang benar dan sesuai dengan gerakan tersebut. Melalui fitur-fitur yang ditampilkan di dalam book creator digital dapat memfasilitasi gaya belajar peserat didik yang berbeda-beda. Baik gaya visual melalui tampilan tulisan dan gambar pada book creator, audio visual dari pesan suara yang ditampilkan pada video serta kinestetik melalui contoh video pembelajaran yang dapat dipraktekkan secara langsung. Keberhasilan seorang guru dalam proses pembelajaran yaitu dengan cara menciptakan suasana pembelajaran yang efektif (Muhammad Yunan Harahap, 2018). Artinya adalah siswa tidak merasa bosan dalam mengikuti proses pembelajaran secara daring. Oleh sebab itu, pemanfaatan media book creator digital ini selain dikemas dalam bentuk digital, siswa dapat terhibur dengan adanya sebuah permainan. Hal ini dapat mengukur tingkat kemampuan siswa dalam memahami materi yang telah dipelajari. Pembelajaran yang dilakukan secara daring tidak menutup kemungkinan siswa sulit memperoleh pengetahuan (Sabaruddin Yunis Bangun, 2016). Melainkan, siswa mampu mendapatkan pengetahuan yang lebih. Yaitu melalui pengalaman belajar yang disajikan dalam book creator tersebut.

Beralihnya pembelajaran pada sistem daring juga meningkatkan proses perpikir siswa dalam memahami pengetahuan. Salah satu contohnya yaitu ketika pembelajaran dilakukan dengan sistem luring tentu siswa berfikir bahwa mengaplikasikan materi yang ada di dalam bahan ajar hanya dapat dipraktekkan dengan adanya contoh dari seorang guru. Sehingga ketika pembelajaran beralih pada sistem daring materi tidak dapat teraplikasikan (Ronaldo Mota David Scott, 2014). Namun adanya kreatifitas seorang guru dalam menyusun strategi pembelajaran, ternyata pembelajaran daring lebih mudah diterapkan secara efektif. Disebabkan guru terbantu dengan keberadaan media pembelajaran yang sesuai dengan tujuan pembelajaran. Selain itu, siswa dapat melakukan praktek secara langsung tanpa bergantung dengan contoh yang ditampilkan oleh guru secara langsung, melainkan mereka dapat melakukan sendiri dengan teknik yang benar di rumah.

Mata pelajaran pendidikan jasmani olahraga dan kesehatan merupakan mata pelajaran yang identik dengan gerakan (Reuchitra, 2018). Artinya setiap organisme pasti mengalami peristiwa perkembangan selama hidupnya yang memiliki sifat kuantitas. Konsep pertumbuhan mengandung definisi sebagai perubahan ukuran fisik 
yang sifatnya pasti. Gerakan-gerakan yang terjadi di dalam tubuh merupakan sebuah koordinasi dalam meningkatkan sebuah ketrampilan.untuk melatih proses perkembangan. Oleh sebab itu, dampak dari pemanfaatan media book creator digital ini juga dapat meningkatkan motorik kasar siswa melalui adanya contoh gerakan yang ada di dalam media tersebut yang bertujuanuntukmemaksimalkan proses perkembangananak.Media book creator digital dapat diakses melalui handphone yang dimiliki oleh siswa, sehingga siswa dapat belajar secara mandiri. Selain itu, dapat melatih berfikir siswa dalam memanfaatkan teknologi untuk hal yang lebih berguna(W, Poluakan, Dikayuana, Wibowo, \& Raharjo, 2020). Tentu hal ini memudahkan seorang guru dalam menstransfer ilmu pengetahuan kepada siswa. Sehingga siswa mendapatkan pengetahuan yang lebih yaitu tidak hanya sebata smengetahui soal, maupun materi saja. Tetapi, siswa dapat mempraktekkan isi materi yang terdapat dalam bahan ajar secara langsung dengan adanya berbantu media pembelajaran yang dapat dimanfaatkannya dalam bentuk menirukan teknik gerakan.

Anak yang memiliki kemampuan motorik kasar yang baik, maka ia akan memiliki perkembangan mental yang baik pula. Karena anak mampu menyesuaikan diri dengan lingkungan sekitarnya, sehingga rasa percaya dirinya akan terus meningkat dan berpengaruh positif pada kemampuan motorik kognitifnya (Reuchitra, 2018).Unsur utama yang berperan penting dalam menstimulasi perkembangan motorik anak-anaka dalah guru dan orang tua. Guru memberikan stimulasi berupa kegiatan yang melibatkan otot-otot kasar anak melalui kegiatan belajar mengajar. Sedangkan orang tua menstimulasi dengan kegiatan yang dapat dilakukan oleh anak sehari-hari yang melibatkan otot-otot pada anak. Guru dapat memantau siswa dengan cara memberikan tugas terkait meniru gerakan sesuai tampilan video pada bahan ajar tersebut. Selanjutnya, siswa mengirimkan hasil prakteknya kepada guru berupa video pada hanphone. Sehingga guru dapat mengetahui bahwa siswa tersebut memang benar-benar melakukan gerakan di rumah masing-masing dengan bantuan bahan ajar book creature digital. Strategi pembelajaran dalam memanfaatkan book creature digital ini, dapat meningkatkan perkembangan motorik kasar siswa. Selain itu memberikan kenyamanan bagi siswa dalam mempelajari teknik gerak yang benar. Hal ini disebabkan penyajian materi yang cukup menarik serta dapat menimbulkan terjadinya "sugestology" atau "sugestopedia". Pada prinsipnya bahwa sugesti akan mempengaruhi hasil belajar. Dalam hal ini belajar juga mengalami proses "suggestology" yang artinya "percepatan belajar" dan memungkinkan peserta didik untuk belajar dengan kecepatan yang tinggi, dengan upaya yang normal, disertai dengan suasana gembira, sehingga dapat menghasilkan suatu pengalaman belajar yang bermakna.

\section{KESIMPULAN}

Pembelajaran yang efektif tentu menjadi suatu keinginan bagi seorang guru. Terutama pada kondisi pandemi saat ini. Berbagai upaya telah dilakukan untuk memaksimalkan proses pembelajaran. Salah satunya yaitu dengan cara memilih 
strategi pembelajaran yang tepat. Penggunaan metode, serta pemilihan media merupakan aspek penting dalam proses pembelajaran. Pemanfaatan teknologi yang berkembang pesat menjadi sebuah alat yang dapat digunakan oleh guru dalam memadupadankan isi materi dengan teknologi. Oleh sebab itu media book creator digital ini dapat dijadikan sebagai salah satu upaya dalam menciptakan pembelajaran yang efektif. Pemanfaatan media book creator digital ini juga dapat meningkatkan perkembangan motorik kasar anak. Yaitu melalui adanya suatu gerakan-gerakan sederhana yang dapat melenturkan tubuh. yaitu dengan cara siswa melihat materi dan menirukan gerakan yang ada di dalam media tersebut untuk memaksimalkan proses perkembangan. Pembelajaran yang dilakukan dengan sistem daring tidak akan menghambat pengetahuan siswa yang tahu akan pentingnya pendidikan melainkan menambah wawasan siswa serta menumbuhkan kreatif siswa dalam memunculkan ide-ide yang baru.

\section{DAFTAR PUSTAKA}

A Cherly. (2004). Motor Learning and Control for Practitioners. The McGraw Hill Companies.

Hamalik. (2003). Pendidikan Kurikulum. Manajemen Pengembangan Kurikulum, Bandung: PT. Remaja Rosda Karya.

Isran Rasyid Karo-Karo S, . Rohani. (2018). Manfaat Media dalam Pembelajaran. Axiom, VII(1).

Junior Tri Dicky. (2019). The Effect of Motor Ability Level on Taekwondo Kick Learning Outcome Through Reciprocal Teaching Style. JPJO, 6(5).

Kaur, J. (2017). Effect of Fine Motor Skill Training on Decoding Skills in School Going Children. International Journal of Science and Research, 6(5), 470-473.

Lee, Eun, Jun., \& Gao, Z. (2020). Effects of the iPad and Mobile Application Integrated Physical Education on Children's Physical Activity and Psychosocial Beliefs. Physical Education and Sport Pedagogy. 2020.

Mahmud, B. (2018). Urgensi Stimulasi KemampuanMotorik Kasar pada Anak Usia Dini.12(1).

Oommen Elsa Babitha. (2020). Impact of Social Media on Sustainable Development. International Journal of Science and Research, 9(11), 1689-1691. https:/ / doi.org/10.21275/SR201126192153

Pramono, H. (2012). Pengaruh Sistem Pembinaan, Sarana Prasarana Dan Pendidikan Latihan Terhadap Kompetensi Kinerja Guru Pendidikan Jasmani Sekolah Dasar Di Kota Semarang. Penelitian Pendidikan, 29(1).

Purba, E. (2015). Pengaruh Strategi Pembelajaran dan Kecerdasan Adversiti Terhadap Hasil Belajar Evaluasi Hasil Belajar. Teknologi Pendiidikan, 17(1).

Bangun, Y., S. (2016). Peran Pendidikan Jasmani dan Olahraga Pada Lembaga Pendidikan di Indonesia. Publikasi Pendidikan, 6(3).

Harahap, YM. (2018). Kondisi dan Suasana Pembelajaran yang efektif. Al-Fikru, 12(2). Maiti, \& Bidinger. (2020). Hambatan Guru Pendidikan Jasmani Generasi 80-An dalam 
Pembelajaran Daring di Tengah Pandemi Covid-19. Journal of Chemical Information and Modeling.

Makdis, N. (2020). Penggunaan E-book Pada Era Digital. Maktabah, 19.

Makmur, T. (2019). Teknologi Informasi. Perpustakaan Dan Ilmu Informasi, 2(1).

Marsudi. (2013). Hakekat kurikulum dan prisip-prisip pengembangan kurikulum. Educational Research and Evaluation.

Nur, L. (2019). Kemampuan Motorik Dasar Anak Usia Dini Dalam Pembelajaran Akuatik. Jurnal Ilmiah, 4(2).

Nurhannisah. (2017). Pengembangan Bahan Ajar Interaktif Untuk Meningkatkan Kemampuan Pemahaman Konsep Matematika pada Siswa SMK Kelas X. Universitas Negeri Yogyakarta: Tesis.

Purnasari, D., P. (2020). Pemanfaatan Teknologi Dalam Pembelajaran Sebagai Upaya Peningkatan Kompetesnsi Pedagogik. Jurnal Publikasi Pendidikan, 10(3), 189-196.

Puspitasari, V. (2020). Pengembangan Perangkat Pembelajaran dengan Model Differensial Menggunakan Book Creator untuk Pembelajaran BIPA di Kelas yang Memiliki Kemampuan Beragam,. Education and Development, 8(4).

Reuchitra. (2018). Effect of Motor Skills Acquisition Training on Gross Motor Skills of Autistic Children. International Journal of Science and Research, 7(9), 35-48.

Ricky Wirasasmita., E. H. (2020). Analisis Efisiensi Kinerja Pendidik terhadap Hasil Pembelajaran Pendidikan Jasmani pada Siswa Sekolah. Mimbar Pendidikan, 5(1).

Rismayanthi, C. (2011). Optimalisasi Pembentukan Karakter dan Kedisiplinan Siswa Sekolah Dasar Melalui Pendidikan Jasmani Olahraga dan Kesehatan. . . Jurnal Pendidikan Jasmani Indonesia, 8(1).

Ruddamayanti. (2019). Pemanfaatan Buku Digital dalam Meningkatkan Minat Baca. Prosiding Seminar Nasional Pendidikan Program Pascasarjana Universitas PGRI Palembang.

Scott, D, M, R. (2014). Education for Innovation and Independent Learning. 5th February.

Seiichiro, K. (2020). The Potential of Lesson Study in Primary Physical Education: Messages from a Longitudinal Study in Japan. Journal European Physical Education Review. 20(10).

Suci, D. A. (2020). Kinerja Guru Pendidikan Jasmani Olahraga Dan Kesehatan Di masa New Normal Covid-19. Jurnal Kesehatan Medika Saintika. Kesehatan Media Saintika, 11(2).

Sudibyo, L. (2011). Peranan dan Dampak Teknologi Informasi dalam Dunia Pendidikan di Indonesia. Widyatama, 2(2), 22.

Sumantri, S. (2017). Teori dan Praktek di Tingkat Pendidikan Dasar. In Raja Grafindo Persada.

Syah, Muhibbin. (2011). Psikologi Pendidikan Dengan Pendekatan Baru.

Utami., W., S. (2019). Multiple Intelligences: Platform Global Paling Efektif Untuk Pendidikan Abad Ke-21 Dalam Pendidikan Dan Pembelajaran.

W, R. W. A., Poluakan, M. V., Dikayuana, D., Wibowo, H., \& Raharjo, S. T. (2020). Potret Generasi Milenial pada Era Revolusi Industri 4.0. Focus : Jurnal Pekerjaan 
Journal Continuous Education

Volume 2, Issue 2, July 2021

Page 23-35

Sosial. https:/ /doi.org/10.24198/ focus.v2i2.26241

Wahyuningtyas, R., \& Sulasmono, B. S. (2020). Pentingnya Media dalam Pembelajaran

Guna Meningkatkan Hasil Belajar di Sekolah Dasar. Edukatif: Jurnal Ilmu Pendidikan. https://doi.org/10.31004/edukatif.v2i1.77 